\title{
The History of African Village Chickens: an Archaeological and Molecular Perspective
}

\author{
J. M. Mwacharo • G. Bjørnstad • J. L. Han • \\ O. Hanotte
}

Published online: 3 March 2013

(C) The Author(s) 2013. This article is published with open access at Springerlink.com

\begin{abstract}
The history of the introduction and dispersal of village chickens across the African continent is a subject of intense debate and speculation among scholars. Here, we synthesize and summarise the current scientific genetic and nongenetic knowledge in relation to the history of the species on the continent. Sociocultural, linguistic, archaeological and historic data all suggest a complex history for the species in Africa, characterized by multiple maritime and/or terrestrial introductions over time and several dispersal routes towards and within Africa. Molecular genetics information supports these observations and in addition suggests possible Asian centers of origin for African domestic chickens, including South Asia and Island Southeast Asia. However, both sets of data were until now too limited in their geographic scope, both within Africa and in comparison with chickens from Asia, to unravel the history of the species in detail. We anticipate that further continent-wide studies combining archaeological, ancient and/or modern genetic information may shed new insights on
\end{abstract}

Electronic supplementary material The online version of this article (doi:10.1007/s10437-013-9128-1) contains supplementary material, which is available to authorized users.

J. M. Mwacharo $(\bowtie) \cdot$ O. Hanotte $(\bowtie)$

Centre for Genetics and Genomics, School of Biology, University of Nottingham, University Park,

Nottingham NG7 2RD, UK

e-mail: joram.mwacharo@nottingham.ac.uk

e-mail: olivier.hanotte@nottingham.ac.uk

G. Bjørnstad · J. L. Han • O. Hanotte

International Livestock Research Institute, P.O. Box 30709, Nairobi 00100, Kenya

G. Bjørnstad

Department of Archaeology, Conservation and History, University of Oslo, P.O. Box 1008, Blindern, 0315 Oslo, Norway

J. L. Han

CAAS-ILRI Joint Laboratory on Livestock and Forage Genetic Resources, Institute of Animal

Science, Chinese Academy of Agricultural Sciences (CAAS), Beijing 100094, China 
the history of the species. These will contribute to a deeper understanding of the history of trading networks and human interactions within Africa and between African and Asian societies, at the root of the development and expansion of African civilizations.

Résumé L'histoire des introductions et des dispersions des poulets de village sur le continent africain reste un sujet fortement débattu et plein de spéculations parmi les experts. Ici, nous synthétisons et résumons nos connaissances génétiques et autres en rapport avec l'histoire de cette espèce domestique sur le continent. Les évidences socio-culturelles, linguistiques, archéologiques et historiques suggèrent toutes une histoire complexe de l'espèce en Afrique caractérisée par de multiples introductions maritimes et/ou terrestres, ainsi que plusieurs routes de dispersions vers l'Afrique et sur le continent. Les informations de la génétique moléculaire supportent ces observations et en plus, elles identifient les centres possibles d'origines, lesquels incluent le Sud de l'Asie et les îles de l'Asie du Sud-Est. Cependant, toutes ces évidences sont jusqu'à présentes trop limitées au niveau géographique, au sein du continent Africain et en Asie, pour révéler en détails l'histoire de l'espèce. Nous anticipons que de nouvelles études sur une grande échelle géographique associant des informations archéologiques et génétiques (ADN ancien et moderne) pourraient apporter de nouvelles lumières sur l'histoire de l'espèce. Celles-ci contribueront à une compréhension plus profonde de l'histoire des réseaux commerciaux et des interactions entre sociétés africaines, ainsi ainsi qu'entre sociétés africaines et asiatiques. Interactions qui sont à la base du développement et de l'expansion des civilisations africaines.

Keywords Africa $\cdot$ Chicken · Gallus gallus · Migration · Trading routes

\section{Introduction}

Domestic chickens are closely associated with humans, and they rely entirely upon humans for their dispersal and indirectly for their survival. The species are therefore important biological markers of agricultural, trade and cultural contacts between societies and civilizations. They are present across the African continent where free-range, scavenging village chickens are found in all agroecological zones, ranging from villages in the humid and subhumid tropical rain forests of West and Central Africa to the temperate highlands of East Africa and the arid and semi-arid regions of the Sahel and Kalahari deserts (http://dad.fao.org/; DAGRIS 2007). With an estimated total population of 1.6 billion at the end of 2010 (FAOSTAT 2012), they are the most abundant livestock species in Africa, contributing to a significant part of the continent's agricultural economy.

Although the African continent is rich in galliform species, the recognized main wild ancestor of domestic chickens, the red junglefowl Gallus gallus, is endemic to sub-Himalayan northern India, southern China and Southeast Asia (Delacour 1977), where the putative centers of domestication of the species are present (TixierBoichard et al. 2011). Therefore, domestic chickens, though abundant on the continent, are an introduced species from Asia. Whether or not the species was 
domesticated in a single geographic area in Southeast Asia (Fumihito et al. 1994, 1996) or across the geographic range of the wild ancestor in both South and Southeast Asia (Liu et al. 2006, Kanginakudru et al. 2008) is still disputed today.

Opinions among scholars are divided concerning when the species arrived and the routes by which chickens entered and dispersed across the continent (GiffordGonzalez and Hanotte 2011). Archaeological data are patchy (Fuller et al. 2011) while molecular genetic information is just starting to emerge (Gifford-Gonzalez and Hanotte 2011).

In this paper, we review the information available today (sociocultural, linguistic, archaeological and molecular genetic) on the arrival and movement of chickens across the African continent, providing a proxy for our understanding of ancient and modern human interactions and migrations, including trading routes within Africa and between the African continent and civilizations across Asia.

\section{Sociocultural and Linguistic Evidence}

Although the primary reason for the introduction of chickens in Africa, whether ritual or alimentary, has remained a subject of active supposition (MacDonald and Edwards 1993), their arrival on the continent ushered in a major milestone in agricultural history and revolutionized the culture of most African societies. Not only were chickens an additional source of valuable animal protein with low husbandry requirements, they were also easily available as sacrificial animals for various sociocultural functions and economic transactions. More particularly, MacDonald (1992, 1995a, b) recognizes that in some modern-day African societies, the sociocultural significance of chickens is exceptional, indicating either a late arrival and quick integration of the species into African customs and traditions or a long-term presence on the continent (Table 1). Such high sociocultural significance raises important questions, such as when and why the species became so crucial in mythology, ritual and iconographic contexts (Guèye 1998; Sonaiya et al. 1999; Kondombo et al. 2003).

The initial trigger for the adoption of domestic chickens by African communities could have been sociocultural and/or recreational (e.g., cockfighting) rather than as a new source of food. Textual records indicate that chickens were already present in Egypt by the time of the Third Dynasty of Ur (c. 2,113-2,006 BC), and the oldest recognizable occurrence of the bird in art dates from the second half of the fourteenth century BC (Haller 1954; Smith 1965). Houlihan and Goodman (1986) suggest, however, that the first evidence for its consumption comes from the tomb of Petosiris, which dates to the fourth century BC, though this suggestion has been challenged by MacDonald and Edwards (1993). Houlihan and Goodman (1986) further suggest that chickens were probably brought to Egypt as creatures of curiosity and admiration because of their unusualness and that they did not become a regular feature of the Egyptian farmyard until the Ptolemaic period (304-330 BC). Domestic chickens could have been introduced to the African continent several times, fulfilling different societal needs at different time periods.

Linguistic evidence not only supports a deep embedding of chickens in African cultures and traditions, but also agrees with an early introduction and a complex history of arrival and dispersion of the species. More particularly, Williamson (2000) 
suggests that different geographic distributions, and spread of the three major roots of the word "fowl" across three language phyla, represent at least three separate introductions of domestic chickens to West Africa: two across Central Africa from the East Coast of Africa and one from North Africa across the Sahara. Blench (2008) noted that the origin of the common Malagasy name for chicken, akoho, cannot be assigned definitively to a Bantu or Austronesian language group. Rather, from his analysis, he concludes that all the terminologies relating to domestic animals in Madagascar appear to be derived from languages of the Swahili, with the Comoros Islands being a possible original source of chickens found in Madagascar.

\section{Archaeological and Historic Evidence}

Archaeological evidence for the occurrence of domestic chickens across Africa is summarised in Table 1 and Fig. 1. The data are relatively few, which may reveal that either the domestic species was uncommon in historic times or, perhaps more likely, that the species has remained largely unreported, although it may have been present in archaeological sites. Indeed, from an archaeological point of view, the situation is complicated by the osteological similarities between domestic chicken and African wild galliforms such as the francolin Francolinus $s p$. and guinea fowl Numididae $s p$. (MacDonald 1992). Guinea fowl is both a domestic and wild bird in most parts of Africa, and their skeletal remains, as well as those of the francolin, often occur concurrently with those of domestic chickens on many archaeological sites (MacDonald 1992). A protocol to discriminate bones of large galliforms does exist, but vital diagnostic parts are rare in most archaeological sites due to postdepositional processes that fragment fragile avian bones and prevent exact identification (MacDonald 1992).

The fourth to third millennia $\mathrm{BC}$ have been advanced as the period for the first arrival of domestic chickens in Africa (Chami 2001, 2007). However, these dates have been disputed as the osteological remains used in their calibration are nondiagnostic according to the recommended criteria (MacDonald 1992; Dueppen 2011). In North Africa, domestic chickens are depicted in Egypt from the second millennium BC (Houlihan and Goodman 1986). In sub-Saharan Africa, the earliest widely accepted evidence of domestic chickens dates to the mid-first millennium AD in Nubia and the late first millennium AD in East and South Africa (e.g., Horton and Mudida, 1993; Plug 1996a, b). In West Africa, several sites attest to the presence of chickens in the late first millennium AD (Table 1). More particularly, while in the Voltaic region evidence for chickens is scarce, researchers working at Daboya (Ghana) have suggested the presence of chickens throughout the first millennium AD (Shinnie and Kense 1989). Until recently, the oldest known, securely identified remains in the western part of the continent were dated to AD 500-850 from JenneJeno in Mali (MacDonald 1995b). New evidence from Kirikongo (Burkina Faso) and Daboya indicates that chickens were already a significant component of the Iron Age economy in West Africa by the sixth century AD at the latest and probably several centuries earlier (Dueppen 2011) (Fig. 1).

Using geographic distribution and dating of the purportedly most ancient, undisputed archaeological evidence in the form of skeletal remains (c. 1,567-1,320 BC), 


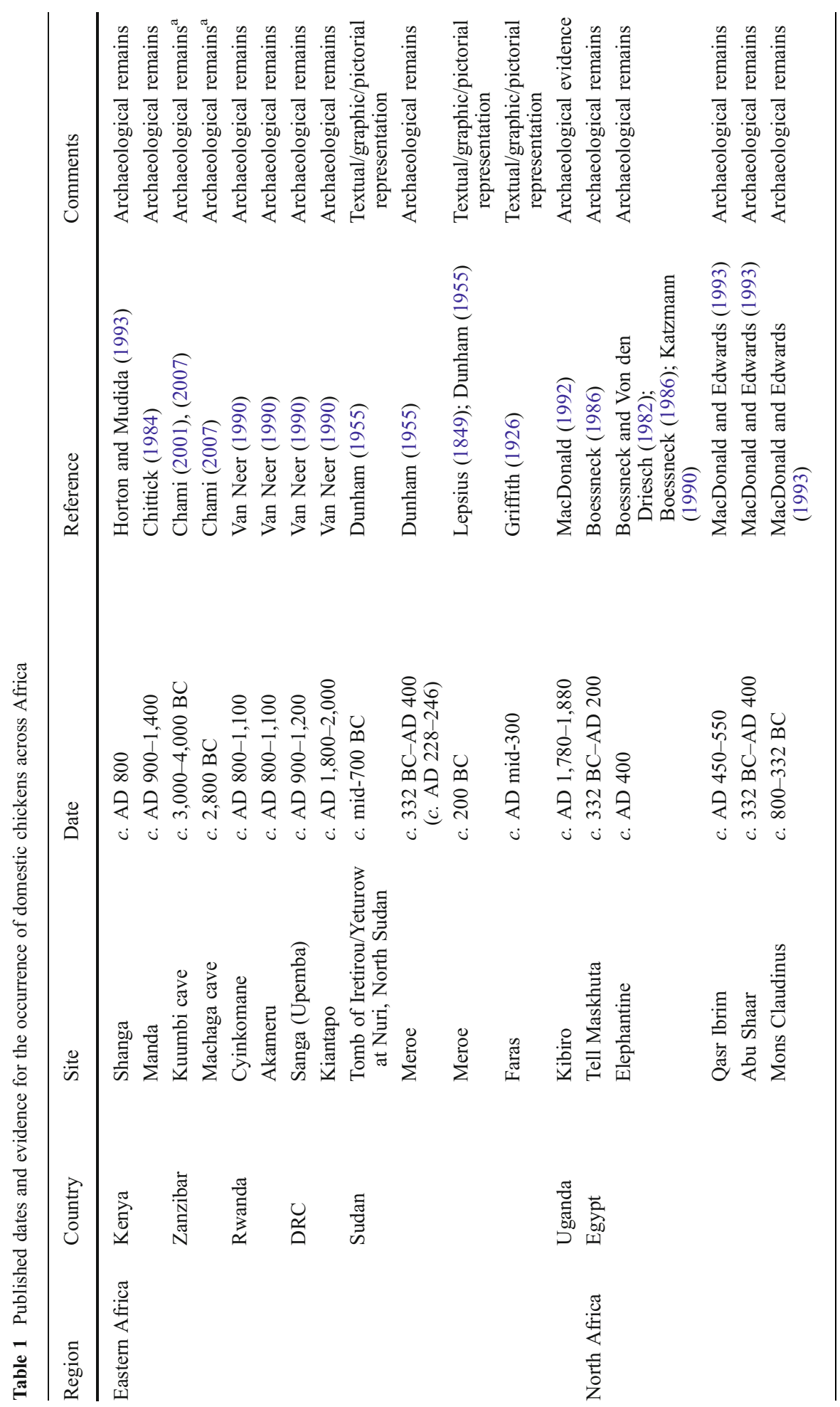




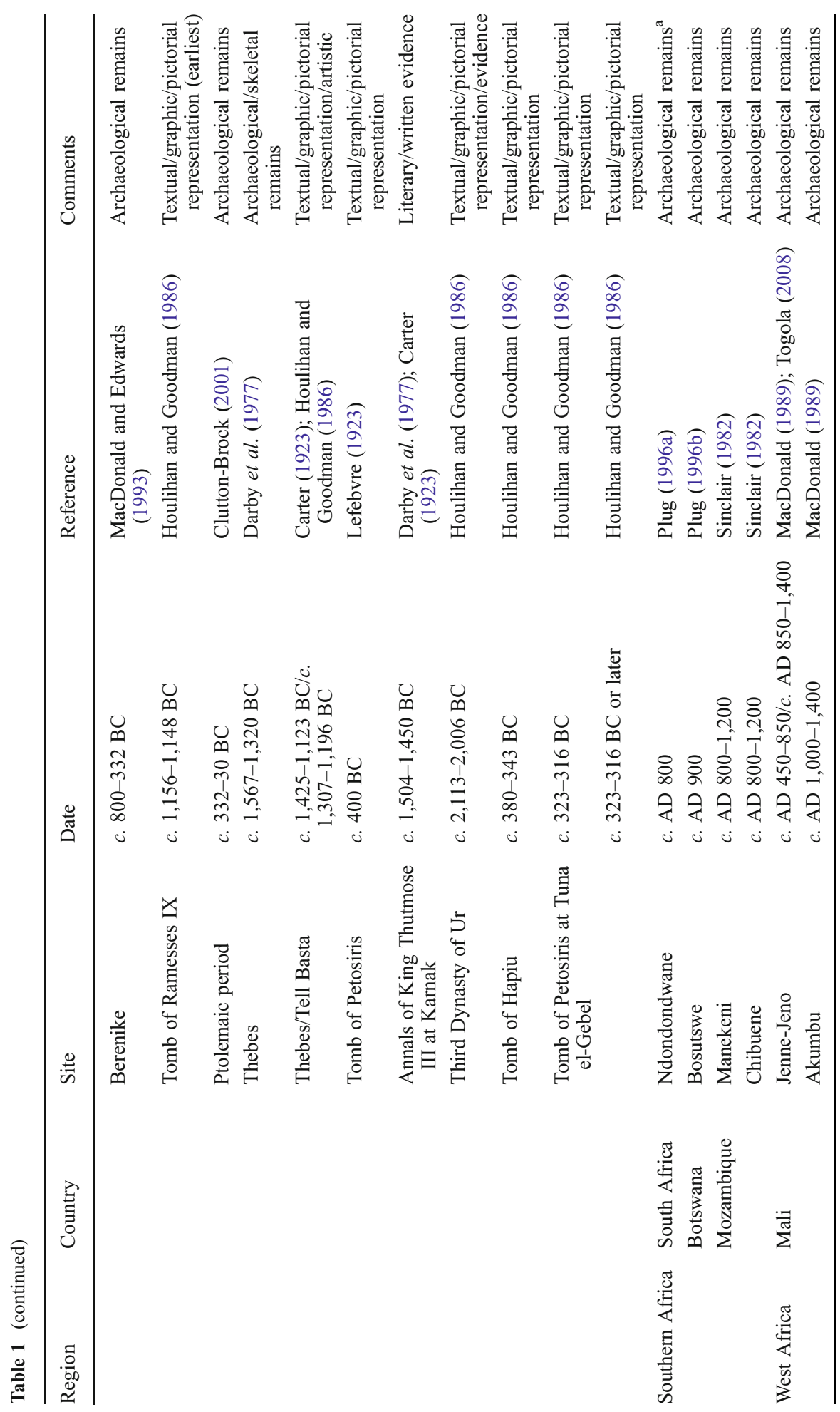




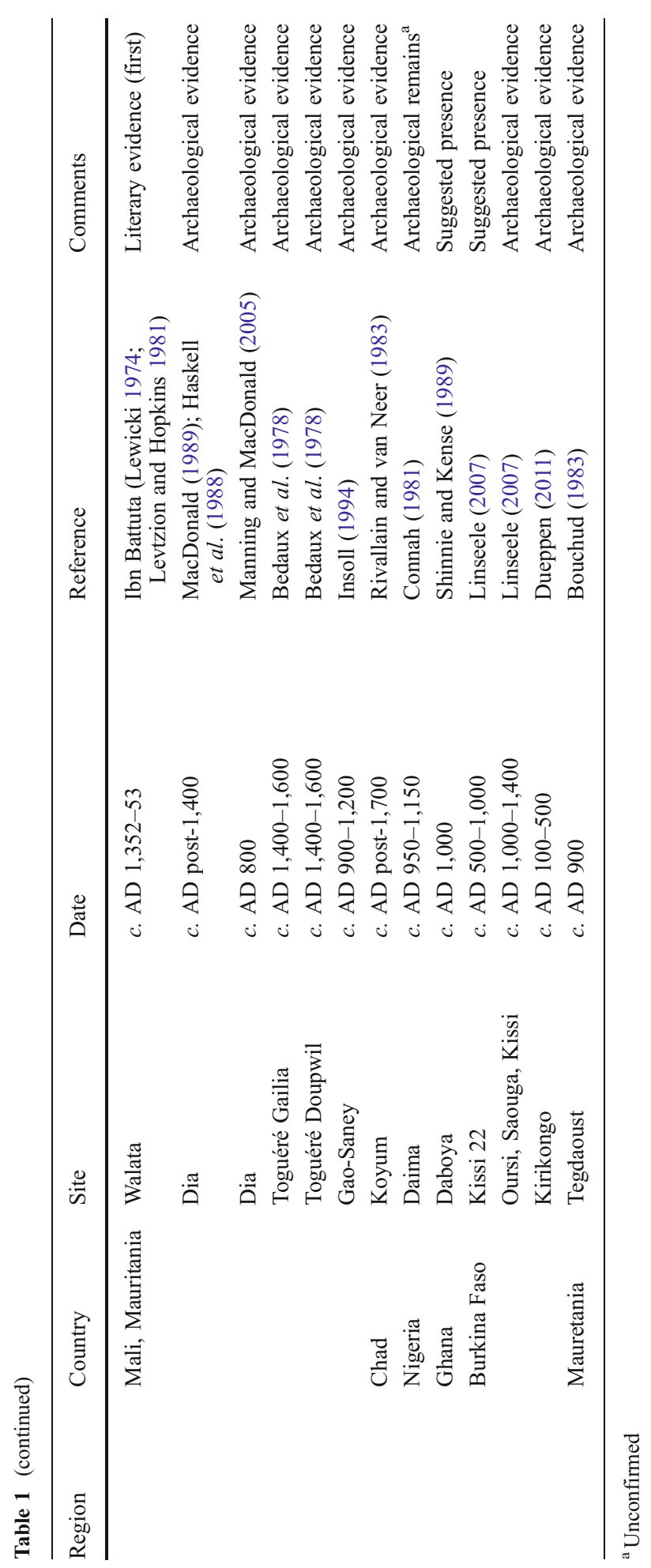



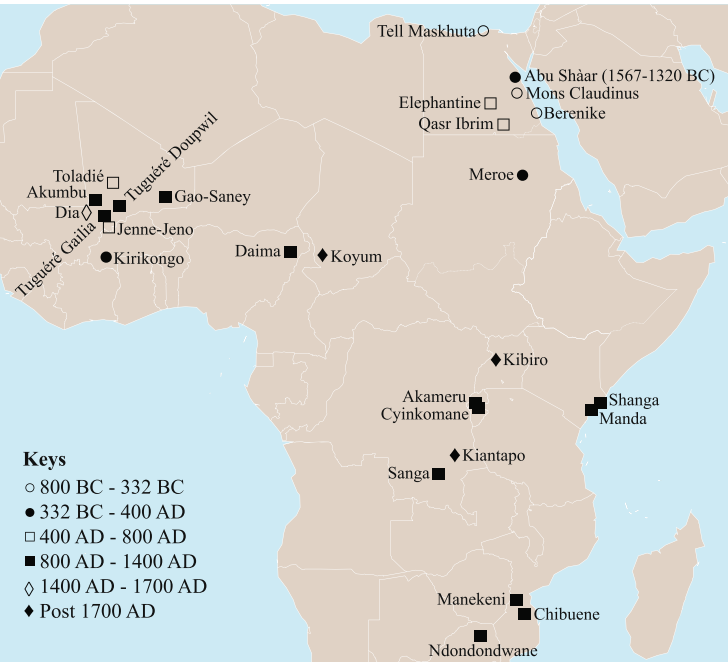

Fig. 1 Summary of archaeological dates for the presence of chicken in different regions across the African continent

pictorial/artistic representations (c. 1,425-1,123 BC) and literary evidence (c. 1,504$1,450 \mathrm{BC}$ ), a commonly held argument is that chickens may have first entered Africa overland through the North of Africa (Egypt), with subsequent dispersion southwards along the Nile valley to Nubia and then in West Africa along the Sudano-Sahelian corridor (MacDonald and Edwards 1993; Fuller et al. 2011). Coltherd (1966) argues that this introduction brought chickens from the Harappan culture of the Indus Valley civilization (c. 2,500-2,100 BC) into Egypt via Mesopotamia. In addition to the Nile corridor, MacDonald and Edwards (1993) further suggest an independent diffusion of chickens into West Africa through the Sudano-Sahelian belt from the East African coast occurring much later, perhaps related to Indian Ocean trade networks.

However, increasing evidence for greater antiquity than previously thought for the Indian Ocean trading network, based largely on the presence of Asian plant domesticates in Africa and of African domesticated plants in South and Southeast Asia, support an early possible entry point of domestic species along the East African coast (Fuller et al. 2011). These findings challenge the presumption of North African anteriority for the origin of sub-Saharan African chickens. A component of this early maritime trading network has been described in some detail in the Periplus of the Erythraean Sea from the early first century AD (Casson 1989; Cappers 2006). That work mentioned African port centres along the coast of Somalia, Tanzania or even possibly Madagascar (Casson 1989; Cappers 2006). Chami (1999) has also reported evidence confirming the great antiquity of trading networks in the Indian Ocean interaction sphere, lending support to the observations of the Periplus. As summarised in Blench (2010), it is likely that there were regular contacts between Island Southeast Asia and the East African coast prior to the first centuries AD, independent from the establishment of Austronesians in Madagascar around the fifth century AD 
(Blench 2010). Lastly, the inclusion of East Africa into a maritime trading network extending eastward to Southwestern China is illustrated by the visit of Chinese fleets under the command of Cheng Ho off the coast of East Africa, although at a much more recent date, the beginning of the fifteenth century AD (Duyvendak 1939).

Undoubtedly, the complex and ancient interactions resulting from the Indian Ocean trading networks must have facilitated maritime and terrestrial intercontinental translocations of several domestic and nondomestic plant and animal species among Africa, the Middle East and South, Southeast and East Asia (Boivin and Fuller 2009; Fuller and Boivin 2009; Fuller et al. 2011). It would not be surprising that domestic chickens would have been an intrinsic part of these translocation packages in historic times and possibly much earlier than the introductions via the north of the continent.

The arrival of European settlers as part of the development of the terrestrial and maritime empires of several European nations across Africa and Asia (Portugal, Britain, etc.) from the fifteenth century AD onwards provided further opportunities for the arrival and movement of chickens within Africa. Also, since the second half of the twentieth century, the African continent, as other parts of the world, has witnessed the arrival of exotic chicken breeds developed for higher productivity (Kitalyi 1997), including for crossbreeding purposes with local flocks to improve meat and egg production. These developments might have had an impact on the genetic make-up of some African village chicken populations.

\section{Molecular Genetic Perspectives}

No molecular genetic study has so far attempted to illustrate and understand the genetic diversity and origin of African indigenous chickens at the continental level (Gifford-Gonzalez and Hanotte 2011). Also, there are no published data on ancient DNA sequence information for the same species in Africa. Currently, all molecular genetic studies have been limited to either individual countries or at best a few of them (Table 2 and 3). These genetic studies may be grouped in two separate sets according to the genetic markers of interest: microsatellite loci (Table 2) and mitochondrial DNA D-loop sequences (Table 3).

The genetic diversity and relationships between chicken populations from several African countries have now been investigated using autosomal microsatellite markers (Table 2). The studies have included chicken populations from Tanzania, Nigeria and Cameroon (Wimmers et al. 2000); Kenya and East Africa (Sudan, Ethiopia, Uganda) (Mwacharo et al. 2007); Zimbabwe, Malawi and Sudan (Muchadeyi et al. 2007); Ethiopia (Dessie 2007; Hassan et al. 2009; Dana 2011; Goraga et al. 2011); South Africa (Mtileni et al. 2010); Benin (Youssao et al. 2010); Ghana (Osei-Amponsah et al. 2010); Egypt (Eltanany et al. 2011); and Benin, Côte d'Ivoire, Ghana, Morocco and Cameroon (Leroy et al. 2012). Although the markers used in these studies overlap to a large extent, with the recommended set of ISAG-FAO microsatellite markers (FAO 2011), no common samples or populations have been used across studies, and this constrains continent-wide analysis.

However, a few important general findings are emerging. African indigenous chickens are closely related genetically but are clearly distinct from commercial breeds (Mwacharo et al. 2007; Leroy et al. 2012). Their genetic diversities are 
Table 2 Microsatellite studies on indigenous African chicken populations

\begin{tabular}{|c|c|c|c|c|c|}
\hline Studies & Countries & $\begin{array}{l}\text { Indigenous } \\
\text { populations }\end{array}$ & $\begin{array}{l}\text { Number } \\
\text { of birds per } \\
\text { population }\end{array}$ & $\begin{array}{l}\text { Number of } \\
\text { microsatellite } \\
\text { loci }\end{array}$ & $\begin{array}{l}\text { Overlapping } \\
\text { markers with } \\
\text { FAO/ISAG }^{\mathrm{f}}\end{array}$ \\
\hline \multirow{3}{*}{$\begin{array}{l}\text { Wimmers } \\
\text { et al. }(2000)\end{array}$} & Tanzania & 7 & 20 & 22 & None \\
\hline & Nigeria & 7 & 4 to 15 & 22 & None \\
\hline & Cameroon & 1 & 18 & 22 & None \\
\hline \multirow{4}{*}{$\begin{array}{l}\text { Mwacharo } \\
\text { et al. (2007) }\end{array}$} & Kenya & 10 & 28 to 54 & 30 & 30 \\
\hline & Uganda & 2 & 40 & 30 & 30 \\
\hline & Ethiopia $^{\mathrm{a}}$ & 2 & 40 and 42 & 30 & 30 \\
\hline & South Sudan & 1 & 37 & 30 & 30 \\
\hline \multirow{3}{*}{$\begin{array}{l}\text { Muchadeyi } \\
\text { et al. (2007) }\end{array}$} & Zimbabwe & 5 & 37 to 51 & 29 & 28 \\
\hline & Malawi & 1 & 60 & 29 & 28 \\
\hline & Sudan $^{\mathrm{f}}$ & 1 & 48 & 29 & 28 \\
\hline Dessie (2007) & Ethiopia $^{\mathrm{b}}$ & 5 & 25 & 10 & 9 \\
\hline $\begin{array}{l}\text { Hassan } \\
\text { et al. (2009) }\end{array}$ & Ethiopia $^{c}$ & 7 & 14 to 23 & 7 & None \\
\hline $\begin{array}{l}\text { Goraga } \\
\text { et al. }(2011)\end{array}$ & Ethiopia $^{\mathrm{d}}$ & 5 & 30 to 33 & 26 & 25 \\
\hline Dana (2011) & Ethiopia $^{\mathrm{e}}$ & 5 & 49 to 52 & 20 & 20 \\
\hline $\begin{array}{l}\text { Mtileni } \\
\text { et al. (2010) }\end{array}$ & South Africa & 2 & 30 and 42 & 29 & 28 \\
\hline $\begin{array}{l}\text { Youssao } \\
\text { et al. }(2010)\end{array}$ & Benin & 2 & 60 and 61 & 22 & 22 \\
\hline $\begin{array}{l}\text { Osei-Amponsah } \\
\text { et al. }(2010)\end{array}$ & Ghana & 2 & 55 and 59 & 22 & 22 \\
\hline $\begin{array}{l}\text { Eltanany } \\
\text { et al. }(2011)\end{array}$ & Egypt & 1 & 27 & 29 & 28 \\
\hline \multirow{5}{*}{$\begin{array}{l}\text { Leroy } \\
\text { et al. (2012) }\end{array}$} & Benin & 7 & 8 to 38 & 22 & 22 \\
\hline & Côte d'Ivoire & 5 & 17 to 41 & 22 & 22 \\
\hline & Ghana & 6 & 6 to 27 & 22 & 22 \\
\hline & Kingdom of Morocco & 1 & 45 & 22 & 22 \\
\hline & Cameroun & 4 & 5 to 30 & 22 & 22 \\
\hline
\end{tabular}

\footnotetext{
a Jimma, Debre Berhan

b Tilili, Horro, Chefe, Jarso, Tepi

${ }^{\mathrm{c}}$ South Gondar, Awi, West and East Gojam

${ }^{\mathrm{d}}$ North-Mekele, Gonder-Zuria, Haremaya, Dodota, Arbaminch-Zuria

${ }^{\mathrm{e}}$ Konso, Sheka, Horro, Mandura, Farta

${ }^{\mathrm{f}}$ Location of the sampling within the country unknown
}

roughly comparable across studies/populations and correspond to the values usually observed in other free-range scavenging chicken populations worldwide, but they are much higher than those observed in commercial breeds (e.g., Wimmers et al. 2000; Osei-Amponsah et al. 2010; Leroy et al. 2012). This diversity may indicate a higher effective population size for introduced African village chickens compared to commercial chickens, and/or ancient population admixture following multiple 
Table 3 Mitochondrial DNA studies on ondigenous African chicken populations

\begin{tabular}{|c|c|c|c|c|c|c|c|c|}
\hline \multirow[t]{2}{*}{ Studies } & \multirow[t]{2}{*}{ Countries } & \multirow{2}{*}{$\begin{array}{l}\text { Indigenous } \\
\text { populations }\end{array}$} & \multirow{2}{*}{$\begin{array}{l}\text { Number of } \\
\text { samples }\end{array}$} & \multicolumn{5}{|c|}{ Haplogroup frequency $(\%)^{\mathrm{a}}$} \\
\hline & & & & A & B & C & D & E \\
\hline $\begin{array}{r}\text { Razafindraibe } \\
\text { et al. (2008) }\end{array}$ & Madagascar & 2 & 77 & $84 \%$ & - & - & $16 \%$ & - \\
\hline \multirow{3}{*}{$\begin{array}{l}\text { Muchadeyi } \\
\text { et al. (2008) }\end{array}$} & Zimbabwe & 5 & 99 & $55 \%$ & - & - & $45 \%$ & \\
\hline & Malawi & 1 & 19 & $100 \%$ & - & - & - & - \\
\hline & Sudan & 1 & 20 & - & - & - & $100 \%$ & - \\
\hline $\begin{array}{l}\text { Adebambo } \\
\text { et al. }(2010)\end{array}$ & Nigeria & 4 & 232 & - & - & - & $100 \%$ & - \\
\hline \multirow{4}{*}{$\begin{array}{l}\text { Mwacharo } \\
\text { et al. }(2011)\end{array}$} & Kenya & 12 & 211 & $45 \%$ & $<1 \%{ }^{\mathrm{c}}$ & - & $54 \%$ & - \\
\hline & Ethiopia & 3 & 42 & - & - & $2 \%{ }^{\mathrm{c}}$ & $96 \%$ & $2 \%{ }^{\mathrm{c}}$ \\
\hline & Sudan & 4 & 135 & - & - & - & $98 \%$ & $2 \%$ \\
\hline & Uganda & 4 & 123 & - & - & - & $100 \%$ & - \\
\hline $\begin{array}{l}\text { Mtileni } \\
\quad \text { et al. (2011) }\end{array}$ & South Africa & $2^{\mathrm{b}}$ & 22 & $9 \%^{\mathrm{d}}$ & $5 \%^{\mathrm{c}}$ & $9 \%^{\mathrm{d}}$ & $68 \%$ & $9 \%$ \\
\hline
\end{tabular}

\footnotetext{
${ }^{a}$ Nomenclature according to Mwacharo et al. (2011)

${ }^{\mathrm{b}}$ Field populations only

${ }^{\mathrm{c}}$ Observed in a single bird

${ }^{\mathrm{d}}$ Observed in two birds
}

introductions. Genetic divergence between chicken populations is generally weak (e.g., Osei-Amponsah et al. 2010; Youssao et al. 2010), and it seems to reflect geographic distances between populations (see Mwacharo et al. 2007). However, Goraga et al. (2011) report genetic distinctions between groups of chicken populations from Ethiopia and Mwacharo et al. (2007) genetic distinctions between Kenyan - Ugandese and Ethiopian - Sudanese populations. Also, Leroy et al. (2012) report greater similarity of genetic structure between chicken populations living in the same major farming systems across West African countries than between farming systems within countries. These observations are compatible with a history of multiple introductions of different genetic pools of the species into the regions, chicken movement along specific trading routes, and/or long-term geographic isolation of these populations.

Evidence of genetic introgression between commercial and local populations has recently been demonstrated using microsatellites for populations from Morocco and Cameroon, but not for populations from Benin, Ghana and Côte d'Ivoire (Leroy et al. 2012). Such introgression could be related to the long-term breeding improvement programmes that involve the supply of commercial breeds to local farmers for crossbreeding purposes. However, the impact of such introgressions is limited, possibly due to poor adaptation of exotic birds to village conditions and the preference of consumers for local chickens.

Only a few molecular genetics studies have now been published on African chickens using maternally inherited mitochondrial DNA (mtDNA) (Razafindraibe et al. 2008; Adebambo et al. 2010; Muchadeyi et al. 2008; Mtileni et al. 2011; 
Mwacharo et al. 2011) (Table 3). Fortunately, these studies have all analysed a hypervariable region of the molecule, the D-loop, which allows comparison across studies. Unfortunately, there is no standardized nomenclature for the chicken mtDNA haplogroups identified across the African studies. So far, the largest study is the one by Mwacharo et al. (2011). It includes mtDNA sequences from 512 domestic chickens from four East African countries (Kenya, Ethiopia, Sudan and Uganda). For the sake of comparison, we have therefore adopted the nomenclature of Mwacharo et al. (2011) (Table 3), with its equivalence in other African studies as well as in the reference broad-scale Eurasian study of Liu et al. (2006) presented in supplementary Table S1.

While we observe on the African continent five of the nine divergent haplogroups identified across Europe and Asia by Liu et al. (2006), two haplogroups, A and D, dominate the continent (Table 3). Haplogroup D clearly is found in all the African countries studied and is the most common in all countries with the exception of Madagascar, Zimbabwe and eastern Kenya. It is the only haplogroup so far identified in West Africa, represented there by Nigeria (Adebambo et al. 2010). The next commonest haplogroup is A, which is absent from Uganda, Sudan, Nigeria and Ethiopia but is the commonest in Madagascar, Malawi, Zimbabwe and eastern Kenya. The other haplogroups are observed at very low frequencies in all studies, being present in only one or two birds.

Through a detailed analysis of the geographic distribution of haplogroup A and D across East Africa, Mwacharo et al. (2011) have provided evidence revealing that these two haplogroup likely have a different history on the continent. It has been proposed that African haplogroup A originates from Southeast and/or East Asia (Muchadeyi et al. 2008; Mtileni et al. 2011; Mwacharo et al. 2011) and that it would have been the result of a maritime introduction along the East African coastline (Mwacharo et al. 2011) including Madagascar (Razafindraibe et al. 2008). Following the known history of the peopling of Madagascar, Razafindraibe et al. (2008) have suggested that its origin might be the Indonesian islands. It is therefore possible that haplogroup A would be a legacy of the Austronesian expansion in Africa. However, so far, no studies have attempted to address the relationship between African haplogroup A and the haplogroups observed in local chickens from the Indonesian islands.

Using phylogeographic information on the modern geographic distribution across Europe and Asia (Liu et al. 2006), the Indian subcontinent has been proposed as the initial center of origin for the haplogroup D found in Africa (Muchadeyi et al. 2008; Mtileni et al. 2011; Mwacharo et al. 2011). Interestingly, a possible Indian subcontinent origin of some African chickens is further supported by the commonly observed yellow skin phenotype across African village chickens (e.g., FAO 2009; Dana et al. 2010a; Youssao et al. 2010; Daikwo et al. 2011; Melesse and Negesse 2011; ElSafty 2012). This phenotype has recently been shown at the molecular level to be a legacy of successful introgression of the grey junglefowl Gallus sonneratii, a yet-tobe-domesticated Gallus species with restricted geographic range on the Indian subcontinent, into domestic chicken (Eriksson et al. 2008). However, whether or not these "crossbred" chickens of Indian origin reached the African continent through a maritime and/or terrestrial route remains unknown.

The possible center(s) of origin for chickens harbouring the mitochondrial DNA of haplogroups B, C and E, observed so far at low frequencies on the African continent 
(Table 3), is more speculative. Haplogroup B and C may have reached Africa following recent introductions of improved commercial chickens (Mwacharo et al. 2011). This suggestion is supported by the presence of identical or closely related haplotypes belonging to these haplogroups in European and commercial chickens (Muchadeyi et al. 2008; Dana et al. 2010b). Using microsatellite markers, Leroy et al. (2012) also demonstrated gene flow between commercial and local chickens in some sub-Saharan African countries. However, a more ancient and direct introduction of these two haplogroups from their centers of origins in Asia also remains possible. More data are required to further clarify the origin(s) of these two haplogroups on the African continent.

Haplogroup E is not observed in commercial chickens (Muchadeyi et al. 2008; Dana et al. 2010b). Both Muchadeyi et al. (2008) and Mwacharo et al. (2011), using the study of Liu et al. (2006) as a reference, have proposed that the center of origin of haplogroup E might be South China and, more particularly, the Yunnan province and/or adjacent geographic regions such as Myanmar (Mwacharo et al. 2011). The routes of introduction of this haplogroup into the African continent remain unknown, but its worldwide geographic distribution today (Liu et al. 2006) suggests that it was likely the consequence of a maritime introduction to the African continent. It raises the interesting hypothesis that its arrival might have followed the Chinese maritime trading expeditions across the Indian Ocean (Duyvendak 1939; Beaujard 2005; Mwacharo et al. 2011).

\section{Conclusion and Future Directions}

Sociocultural, linguistic, archaeological, historic and molecular genetic evidence are all in agreement in revealing a complex history of domestic chickens on the African continent, which may include multiple origins from the geographic range of the wild ancestor in Asia, multiple entry points and multiple routes of dispersion. Archaeological data support a relatively ancient presence of this domesticate in Africa, although several thousand years more recent than the earliest evidence of domesticated ruminants on the continent (Gifford-Gonzalez and Hanotte 2011). Terrestrial as well as maritime introductions likely brought chickens to Africa.

However, our knowledge of the history of African village chickens is still in its infancy with several important unknowns. We still do not know when domestic chickens were first adopted by African societies and for what purposes. We have, so far, little information on the likely number of waves that brought chickens into the continent and their time sequence. Also, the terrestrial and maritime dispersal routes of domestic chickens from their centers of origin in Asia to Africa remain largely speculative. Last but not least, our knowledge of the putative entry points and movements of chickens within the African continent is similarly incomplete.

We believe that the answers to these questions will rely on new archaeological and genetic information generated from inside and outside the African continent, with the most promising studies combining calibrated dating of archaeological bones, ancient DNA sequence information and joint analysis of archaeological and molecular genetic diversity data across Africa, Europe and Asia. New genetic marker analysis (autosomal markers, full genome and mitochondrial DNA sequences) will undoubtedly provide 
further information, as has now been illustrated for other African livestock species (e.g., cattle; see Gifford-Gonzalez and Hanotte 2011). In this context, it is important to take note of the fact that we do have at best incomplete molecular genetic information on the modern genetic diversity of indigenous chickens from the Arabian Peninsula, the Middle and the Near East, most of the Indian subcontinent, and large geographic areas in mainland and island Southeast Asia (e.g., Laos, Cambodia, the Philippines, Indonesia). Also, within the African continent, information on the genetic diversity of indigenous chickens is still too fragmentary to allow a comprehensive genetic analysis throughout the continent. Lastly, as reviewed in detail by others (Blench 2003; Boivin and Fuller 2009; Fuller and Boivin 2009; Fuller et al. 2011), chickens were only one of the agricultural species being voluntarily traded between Africa and Asia. Combining different lines of information from other agricultural and nonagricultural organisms that may have travelled as companion species will likely provide new insights and hypotheses about the history of African domestic village chickens.

Acknowledgments We would like to thank Diane Gifford-Gonzalez as well as two anonymous reviewers for their valuable comments on an earlier version of this manuscript. This article was produced as part of ongoing research aiming to better understand and characterize the unique animal genetic resources of the African continent. The research activity is supported by multilateral donor agencies to the International Livestock Research Institute and BBSRC-UK (Biotechnology and Biological Sciences Research Council$\mathrm{UK})$ funding $(\mathrm{BB} / \mathrm{H} 009051 / 1)$ to the corresponding authors.

Open Access This article is distributed under the terms of the Creative Commons Attribution License which permits any use, distribution, and reproduction in any medium, provided the original author(s) and the source are credited.

\section{References}

Adebambo, A. O., Mobegi, V. A., Mwacharo, J. M., Oladejo, B. M., Adewale, R. A., Ilori, L. O., et al. (2010). Lack of phylogeographic structure in Nigerian village chicken revealed by mitochondrial DNA D-loop sequence analysis. International Journal of Poultry Science, 9, 503-507.

Beaujard, P. (2005). The Indian Ocean in Eurasia and African world-systems before the sixteenth century. Journal of World History, 16, 411-465.

Bedaux, R. M. A., Constandse-Westermann, T. S., Hacquebord, L., Lange, A. G., \& van der Waals, J. D. (1978). Recherches archéologiques dans le delta intérieur du Niger. Paleohistoria, 20, 91220 .

Blench, R. M. (2003). The movement of cultivated plants between Africa and India in prehistory. In K. Neumann, A. Butler, \& S. Kahlheber (Eds.), Food, fuel and fields: Progress in African archaeobotany (pp. 273-292). Köln: Heinrich Barth Institut.

Blench, R. M. (2008). The Austronesians in Madagascar and their interaction with the Bantu of the East African coast: Surveying the linguistic evidence for domestic and translocated animals. Studies in Philippine Languages and Cultures, 18, 18-43.

Blench, R. M. (2010). Evidence for the Austronesian voyages in the Indian Ocean. In A. Anderson, O. Barrett, \& K. V. Boyle (Eds.), The global origins and development of seafaring (pp. 239-248). Cambridge: McDonald Institute.

Boessneck, J., \& Von Den Driesch, A. (1982). Studien an subfossilen Tierknochen aus Ägypten. Munich: Deutscher Kunstverlag. Münchner Ägyptologische Studien Heft 40.

Boessneck, J. (1986). Vogelknochenfunde aus dern alten Ägypten. Annalen des Naturhistorischen Museums in Wien, 88(89), 323-344.

Boivin, N., \& Fuller, D. Q. (2009). Shell middens, ships and seeds: Exploring coastal subsistence, maritime trade and the dispersal of domesticates in and around the ancient Arabian Peninsula. Journal of World Prehistory, 22, 113-180. 
Bouchud, J. (1983). Paléofaune de Tegdaoust. In Tegdaoust III: Recherches sur Aoudaghost: Campagnes 1960-1965 (Editions recherche sur les civilisations 25). Paris: Institut mauritanien de la recherché scientifique.

Cappers, R. (2006). Roman foodprints at Berenike: Archaeobotanical evidence of subsistence and trade in the eastern desert of Egypt. Los Angeles: Costen Institute of Archaeology, UCLA.

Carter, H. (1923). An ostracon depicting a red junglefowl (the earliest known drawing of the domestic cock). Journal of Egyptian Archaeology, 9, 1-4.

Casson, L. (1989). The Periplus Maris Erythraei: Text with introduction, translation, and commentary. Princeton: Princeton University Press.

Chami, F. (2001). Chicken bones from a Neolithic limestone cave site, Zanzibar: Contact between East Africa and Asia. In F. Chami, G. Pwiti, \& C. Radimilahy (Eds.), People, contact and the environment in the African past (pp. 84-97). Dar es Salaam: University of Dar es Salaam Press.

Chami, F. A. (1999). Graeco-Roman trade links and the Bantu migration theory. Anthropos, 94(1-3), 205215 .

Chami, F. A. (2007). Diffusion in the studies of the African past: Reflections from new archaeological findings. African Archaeological Review, 24, 1-14.

Chittick, N. (1984). Manda. Nairobi: The British Institute in Eastern Africa.

Clutton-Brock, J. (2001). The spread of domestic animals in Africa. In T. Shaw, P. Sinclair, B. Andah, \& A. Okpoko (Eds.), The archaeology of Africa: Food, metals and towns (pp. 61-70). London: Taylor and Francis Group/Routledge.

Coltherd, J. B. (1966). The domestic fowl in ancient Egypt. Ibis, 108, 217-223.

Connah, G. (1981). Three thousand years in Africa. Cambridge: Cambridge University Press.

DAGRIS (2007). Domestic Animal Genetic Resources Information System (DAGRIS). (Eds. S. Kemp, Y. Mamo, B. Asrat and T. Dessie). International Livestock Research Institute, Addis Ababa, Ethiopia. http://dagris.ilri.cgiar.org. Accessed 14 Feb 2013

Daikwo, I. S., Okpe, A. A., \& Ocheja, J. O. (2011). Phenotypic characterization of local chickens in Dekina. International Journal of Poultry Science, 10, 444-447.

Dana, N. (2011). Breeding programs for indigenous chicken in Ethiopia: Analysis of diversity in productions systems and chicken populations. PhD thesis, Wageningen University, The Netherlands.

Dana, N., Dessie, T., van der Waaij, L. H., \& van Arendonk, J. A. M. (2010). Morphological features of indigenous chicken populations of Ethiopia. Animal Genetic Resources Information, 46, 11-23.

Dana, N., Megens, H.-J., Crooijmans, R. P. M. A., Hanotte, O., Mwacharo, J. M., Groenen, M. A. M., et al. (2010). East Asian contributions to Dutch traditional and Western commercial chickens inferred from mtDNA analysis. Animal Genetics, 42, 125-133.

Darby, W. J., Ghalioungui, P., \& Grivetti, L. (1977). Food: The gift of Osiris (Vol. 1). London: Academic Press.

Delacour, J. (1977). The pheasants of the world (2nd ed.). Hindhead: Spur Publications.

Dessie T. (2007). Phenotypic and genetic characterization of local chicken ecotypes in Ethiopia. PhD thesis, Humboldt-Universität zu Berlin, Berlin, Germany. http://cgspace.cgiar.org/handle/10568/3930. Accessed 14 Feb 2013

Dueppen, S. A. (2011). Early evidence for chicken at Iron Age Kirikongo (c AD 100-1450), Burkina Faso. Antiquity, 85, 142-157.

Dunham, D. (1955). The royal cemeteries of Kush II, Nuri. Boston: Massachusetts Museum of Fine Arts.

Duyvendak, J. J. L. (1939). The true dates of the Chinese maritime expeditions in the early fifteenth century. T'oung Pao, Second Series, 34(5), 341-413.

El-Safty, S. A. (2012). Determination of some quantitative and qualitative traits in Libyan native fowls. Egypt Poultry Science, 32, 247-258.

Eltanany, M., Philipp, U., Weigend, S., \& Distl, O. (2011). Genetic diversity of Egyptian chicken strains using 29 microsatellite markers. Animal Genetics, 42, 666-669.

Eriksson, J., Larson, G., Gunnarsson, U., Bed'hom, B., Tixier-Boichard, M., Strömstedt, L., et al. (2008). Identification of the yellow skin gene reveals a hybrid origin of the domestic chicken. PLoS Genetics, 4 , e1000010.

FAO (2009). Characterization of domestic chicken and duck production systems in Egypt. Prepared by Haitham M. Yakout, Mohamed Kosba and Olaf Thieme. AHBL-Promoting strategies for prevention and control of HPAI. Rome.

FAO (2011). Molecular genetic characterization of animal genetic resources. FAO Animal Production and Health Guidelines, No 9. Rome, Italy. http:/www.fao.org/docrep/014/i2413e/i2413e00.htm. Accessed 14 Feb 2013

FAOSTAT (2012). FAO Statistical Yearbook 2012. FAO, Rome, Italy. http:/faostat.fao.org/. Accessed August 23, 2012. 
Fuller, D. Q., \& Boivin, N. L. (2009). Crops, cattle and commensals across the Indian Ocean: Current and potential archaeobiological evidence. Etudes Ocean Indien, 42(43), $13-46$.

Fuller, D. Q., Boivin, N., Hoogervorst, T., \& Allaby, R. (2011). Across the Indian Ocean: The prehistoric movement of plants and animals. Antiquity, 85, 544-558.

Fumihito, A., Miyake, T., Sumi, S., Takada, M., Ohno, S., \& Kondo, N. (1994). One subspecies of the red jungle fowl (Gallus gallus gallus) suffices as the matriarchic ancestor of all domestic breeds. Proceedings of the National Academy of Sciences of the United States of America, 91, 12505-12509.

Fumihito, A., Miyake, T., Takada, M., Shingu, R., Endo, T., Gojobori, T., et al. (1996). Monophyletic origin and unique dispersal patterns of domestic fowls. Proceedings of the National Academy of Sciences of the United States of America, 93, 6792-6795.

Gifford-Gonzalez, D., \& Hanotte, O. (2011). Domesticating animals in Africa: Implications of genetic and archaeological findings. Journal of World Prehistory, 24, 1-23.

Goraga, Z., Weigend, S., \& Brockmann, G. (2011). Genetic diversity and population structure of five Ethiopian chicken ecotypes. Animal Genetics, 43, 454- 457.

Griffith, F.L. (1926). Oxford excavations in Nubia. Liverpool Annals of Archaeology 6. Anthropology XIII.

Guèye, E. H. F. (1998). Village egg and fowl meat production in Africa. World's Poultry Science Journal, $54,73-86$.

Haller, A. (1954). Die Gräber und Grüfte von Assur. Berlin: Germany.

Haskell, H. W., McIntosh, R. J., \& McIntosh, S. K. (1988). Archaeological reconnaissance in the region of Dia Mali: Final report to the National Geographic Society. Washington D.C.: National Geographic Society.

Hassan, H., Neser, F. W. C., de Kock, A., \& van Marle-Koster, E. (2009). Study on the genetic diversity of native chickens in northwest Ethiopia using microsatellite markers. African Journal of Biotechnology, $8,1347-1353$.

Horton, M., \& Mudida, N. (1993). Exploitation of marine resources: Evidence for the origin of the Swahili communities of East Africa. In T. Shaw, P. Sinclair, B. Andah, \& A. Okpoko (Eds.), The archaeology of Africa: Food, metals and towns (pp. 673-683). London: Taylor and Francis Group/Routledge.

Houlihan, P. F., \& Goodman, S. M. (1986). The birds of ancient Egypt. Warminster: Aris and Phillips Ltd.

Insoll, T. (1994). Preliminary results of excavations at Gao, September and October 1993. Nyame Akuma, $41,45-48$.

Kanginakudru, S., Metta, M., Jakati, R. D., \& Nagaraju, J. (2008). Genetic evidence from Indian red jungle fowl corroborates multiple domestication of modern day chicken. BMC Evolutionary Biology, 8, 174. doi:10.1186/1471-2148-8-174.

Katzmann, L. (1990). Tierknochenfunde aus Elephantine in Oberägyptien (Grabungsjahre 1976 bis 1986/ 87) Vogel, Reptilien, Fische und Mollusken. Doctoral dissertation, Universität München.

Kitalyi, A.J. (1997). Village chicken production systems in developing countries: What does the future hold. World Animal Review 89 (2), http:/www.fao.org/docrep/W6437T/w6437t00.htm\#TopOfPage. Accessed 14 Feb 2013

Kondombo, S. R., Nianogo, A. J. R., Kwakkel, P., Udo, H. M. Y., \& Slingerland, M. (2003). Comparative analysis of village chicken production in two farming systems in Burkina Faso. Tropical Animal Health and Production, 35, 563-574.

Lefebvre, M. G. (1923). Le tombeau de Petosiris 111. Cairo: IFAO.

Lepsius, C.R. (1849-55). Denkmaler aus Aegytpen und Aethiopien. Leipzig.

Leroy, G., Kayang, B. B., Youssao, I. A. K., Yapi-Gnaore, C. V., Osie-Amponsah, R. O., Loukou, N. E., et al. (2012). Gene diversity, agroecological structure and introgression patterns among village chicken populations across North, West and Central Africa. BMC Genet, 13, 34. http:/www.biomedcentral. com/1471-2156/13/34. Accessed 14 Feb 2013

Levtzion, N., \& Hopkins, J. (1981). Corpus of early Arabic sources for West African history. Cambridge: Cambridge University Press.

Lewicki, T. (1974). West African food in the Middle Ages. Cambridge: Cambridge University Press.

Linseele, V. (2007). Archaeofaunal remains from the past 4000 years in Sahelian West Africa: Domestic livestock, subsistence strategies and environmental changes. Oxford: Archaeopress.

Liu, Y. P., Wu, G. S., Yao, Y.-G., Miao, Y.-W., Luikart, G., Baig, M., et al. (2006). Multiple maternal origins of chicken: Out of the Asian jungles. Molecular Phylogenetics and Evolution, 38, 12-19.

MacDonald, K.C. (1989). The identification and analysis of animal bones from West African archaeological sites. BA Honors thesis, Rice University.

MacDonald, K. C. (1992). The domestic chicken (Gallus gallus) in sub-Saharan Africa: A background to its introduction and its osteological differentiation from indigenous fowls (Numidinae and Francolinus sp). Journal of Archaeological Science, 19, 303-318. 
MacDonald, K. C., \& Edwards, D. N. (1993). Chicken in Africa: The importance of Qasr Ibrim. Antiquity, 67, 584-590.

MacDonald, K. C. (1995a). Why chicken? The centrality of the domestic fowl in West African ritual and magic. In K. Ryan \& P. J. Crabtree (Eds.), Animal symbolism and archaeology (pp. 50-56). Philadelphia: MASCA/University of Pennsylvania Press.

MacDonald, K. C. (1995b). The faunal remains (mammals, birds and reptiles). In S. K. McIntosh (Ed.), Excavations at Jenne-Jeno, Hambarketolo and Kaniana (Inland Niger Delta, Mali) (pp. 291-318). Berkeley: University of California Press.

Manning, K., \& MacDonald, K. (2005). Analyse des restes d'animaux collectés à Dia. In R. Bedaux, J. Polet, K. Sanogo, \& A. Schmidt (Eds.), Recherches archéologiques à Dia dans le delta intérieur du Niger (Mali) (pp. 363-385). Leiden: CNWS publications.

Melesse, A., \& Negesse, T. (2011). Phenotypic and morphological characterization of indigenous chicken populations in southern region of Ethiopia. Animal Genetic Resources, 49, 19-31.

Mtileni, B. J., Muchadeyi, F. C., Maiwashe, A., Chimonyo, M., Groeneveld, E., Weigend, S., et al. (2011). Diversity and origin of South African chicken. Poultry Science, 90, 2189-2194.

Mtileni, B. J., Muchadeyi, F. C., Weigend, S., Maiwashe, A., Groeneveld, E., Chimonyo, M., et al. (2010). A comparison of genetic diversity between South African and conserved and filed chicken populations using microsatellite markers. South African Journal of African Science, 40(5), 462-466.

Muchadeyi, F. C., Eding, H., Simianer, H., Wollny, C. B. A., Groeneveld, E., \& Weigend, S. (2008). Mitochondrial DNA D-loop sequences suggest a Southeast Asian and Indian origin of Zimbabwean village chicken. Animal Genetics, 39, 615-622.

Muchadeyi, F. C., Eding, H., Wollny, C. B. A., Groeneveld, E., Makuza, S. M., Shamseldin, R., et al. (2007). Absence of population substructuring in Zimbabwe chicken ecotypes inferred using microsatellite analysis. Animal Genetics, 38, 332-339.

Mwacharo, J. M., Nomura, K., Hanada, H., Jianlin, H., Hanotte, O., \& Amano, T. (2007). Genetic relationships among Kenyan and other East African indigenous chicken. Animal Genetics, 38, 485-490.

Mwacharo, J. M., Bjørnstad, G., Mobegi, V., Nomura, K., Hanada, H., Amano, T., et al. (2011). Mitochondrial DNA reveals multiple introductions of domestic chicken in East Africa. Molecular Phylogenetics and Evolution, 58, 374-382.

Osei-Amponsah, R., Kayang, B. B., Naazie, A., Osei, Y. D., Youssao, I. A., Yapi-Gnaore, V. C., et al. (2010). Genetic diversity of forest and savannah chicken populations of Ghana as estimated by microsatellite markers. Animal Science Journal, 81, 297-303.

Plug, I. (1996a). Domestic animals during the early Iron Age in southern Africa. In G. Pwiti \& R. Soper (Eds.), Aspects of African archaeology (pp. 515-522). Harare: University of Zimbabwe Publications.

Plug, I. (1996b). Seven centuries of Iron Age traditions at Bosutswe, Botswana: A faunal perspective. South African Journal of Science, 92, 91-97.

Razafindraibe, H., Mobegi, V. A., Ommeh, S. C., Rakotondravao, J., Bjørnstad, G., Hanotte, O., et al. (2008). Mitochondrial DNA origin of indigenous Malagasy chicken: Implications for a functional polymorphism at the Mx gene. Annals of the New York Academy of Sciences, $1149,77-79$.

Rivallain, J., \& Van Neer, W. (1983). Les fouilles de Koyom (Sud du Tchad) étude du matériel archéologique et faunique. L'Anthropologie, 87, 221-239.

Shinnie, P. L., \& Kense, E. J. (1989). Archaeology of Gonja, Ghana. Calgary: University of Calgary Press.

Sinclair, P. (1982). Chibuene: An early trading city in Southern Mozambique. In J. de V. Allen \& T. Wilson (Eds.), From Zinj to Zanzibar. Paideuma, 28, 149-164.

Smith, W. S. (1965). Interconnections in the ancient Near East. New Haven: Connecticut, USA.

Sonaiya, E.G., Branckaert, R.D.S., \& Guéye, E.F. (1999). Research and development option for family poultry. In First INFPD/FAO Electronic Conference on Family Poultry, http:/faoext02.fao.org/ waicent/faoinfo/agricult/agap/lps/fampo/intropap.htm. Accessed 14 Feb 2013

Tixier-Boichard, M., Bedd'hom, B., \& Rognon, X. (2011). Chicken domestication: From archaeology to genomics. Comptes Rendus Biologies, 334, 197-204.

Togola, T. (2008). Archaeological investigations of Iron Age sites in the Mema Region, Mali (West Africa). Oxford: Archaeopress.

Van Neer, W. (1990). Les faunes de vertébrés quaternaires en Afrique Centrale. In R. Lanfranchi \& D. Schwartz (Eds.), Paysages Quaternaires de l'Afrique Centrale Atlantique (pp. 289-327). Paris: ORSTOM.

Williamson, K. (2000). Did chicken go west? In R. M. Blench \& K. C. MacDonald (Eds.), The origins and development of African livestock: Archaeology, genetics, linguistics and ethnography (pp. 368-448). London: UCL Press, Taylor and Francis Group. 
Wimmers, K., Ponsuksili, S., Hardge, T., Valle-Zarate, A., Mathir, P. K., \& Horst, P. (2000). Genetic distinctness of African, Asian and South American local chickens. Animal Genetics, 31, 159-165.

Youssao, I. A. K., Tobada, P. C., Koutinhouin, B. G., Dahouda, M., Idrissou, N. D., Bonou, G. A., et al. (2010). Phenotypic characterisation and molecular polymorphism of indigenous poultry populations of the species Gallus gallus of savannah and forest ecotypes of Benin. African Journal of Biotechnology, 9, 369-381. 